\title{
Exploring the Dialectical Relationship between National Discourse and the Family in a Contemporary World
}

\author{
Lakinbofa S. Goodluck
}

School of Media and Communication, Pan-Atlantic University, Lagos

\begin{abstract}
National discourse can be described as any conversation that permeates the generality of a nation. Being the most basic unit of a nation, the centrality of the family to the continuous existence of a nation cannot be overemphasised. This centrality is reflected in how the national discourse of a nation descends to the family, and how events in the family can trigger a national discourse. Predicated on the discourse theory, and using the discourse analysis method to examine purposively selected cases that underpinned national discourses in Nigeria and the United States, the paper examined the symbiotic relationship between national discourse and the family being the smallest unit of a nation. It was discovered that the relationship between national discourse and the family is dialectical, which calls for consciousness on the part of every individual in the family, the media and the nation at large, especially in how national discourses are triggered.
\end{abstract}

Keywords: Discourse, national discourse, nation, family, dialectical, discourse analysis, media, communication.

\section{Introduction}

Communication is a human need that is best fulfilled by a fellow human (Dutta, 2013; Tirumalesh, 1999); and arguably with the family as the primary point of exposure to it. Johnson posits that communicating with others makes people feel more human (Johnson, 1978); in other words, when individuals engage in ordinary natters they feel good about themselves. This is probably why we spend a significant percentage of our daily lives communicating. Scholars (Nadeau, 1969; Buzan, 1984; Hannawa, 2017) have acknowledged that humans spend between 70 and 80 percent of waking hours on some kind of communication, which occurs in diverse settings and places. The subject of human interaction encompasses virtually all aspects of human existence. Some issues become so accentuated that they permeate discourses across boundaries and units of the society, including national boundaries. A discourse that infiltrates every section of a nation's actuality, perhaps, can be pigeonholed as national discourse. The subject of a national discourse can be political, social, economic, religious, or any other matter that affects the existence of a people; and can be influenced by both local and happenings in other nations. This reality is further intensified by the incidence of globalisation which has potted the world into a global village. 
The family as a basic unit of any society (Enrique, Howk, \& Huitt, 2007) represents an essential component of a nation. Corbett $(2004$, p. 3) describes family as a unit of persons linked by natural familial links (most basically and ideally consisting of a father and mother with their children), or in a manner that morally and legally reproduces these natural genealogical associations, such as adoption. It is perhaps the smallest unit of a nation, yet central to national discourse. In actual fact every national discourse should be evaluated in relation to its effect on the family. The logic in this proposition is driven by the realism that every member of a nation belongs to a family, and whatever happens in the family, to a considerable degree, affects each member of the family. Likewise, whatever happens to a member of a family, to a large extent, affects the whole family.

Based on this premise, it is arguable that national discourse filters into the family and its imports impact the family in some ways. In the same vein, a casual family conversation can transcend or pierce into national discourse. It thus connotes that the relationship between national discourse and family is dialectical and symbiotic; they impact each other. This reality is a worldwide phenomenon that cuts across diverse ethnicities, races, religions and territorial delineations. In effect, that national discourse can be influenced by occurrences outside a nation's borders means a family can be impacted by events and discourses in other nations beyond its geographical definition. It is essential to point out that national discourse can have both positive and negative implications on the family as evident during the Ebola outbreak in Nigeria. The disease formed the theme of the prevailing national discourse at the time, which helped many Nigerians to be more aware of the disease and took necessary precautions. In the same way the discourse created palpable fear in the nation to the extent that some people opted not to interact with anyone that showed any sign of ailment, including family members.

Many treatises have been written on national discourse and its impact on the society. Many of these discourses have essentially examined national discourse from the nationalist and political perspectives (Parekh, 1995; Eastmond, 1998). Although, the family is often implicit in any thesis on national discourse; however, not many have explored the dialectical relationship between occurences in the family and the themes of national discourses. Isolating this dialecticism is apposite bearing in mind that the family is central to the existence of a nation (Conrad, 2004). To that extent, a loose perspective on the interaction between the happenings in a family and national discourse can pose a threat to the survival of a nation. Correspondingly, stimulating a national discourse without appropriate consideration for its possible effects on individual family units can be venturesome on the family, and turnabout to hurt the nation. In other words, every form of national discourse can either uphold the individual family unit or endanger it. In the same vein, an occurrence within a family has the potential to strengthen or threaten the perpetuity of a nation through the prevalent discourse.

Grounded on the discourse theory and employing the discourse analysis method, this paper explores the symbiotic relationship between national discourse and the family. The cases that have been purposively chosen are representative of national discourse subjects in two countries - Nigeria and United States of America. Some of the cases were subjects of discourses across international borders, whilst some were essentially pervasive within the particular nation. In addition to personal observation of the researcher who closely monitored the discourses, the analysis of selected cases was predicated on available online resources that are free of legal restrictions, and have not been refuted by personalities involved. Inasmuch, as the selected cases may not be sufficient for a generalisation, which obviously places a limitation on the generalisability of the propositions herein, there are persuasive inferences to posit that the relationship between national discourse and the family is dialectical.

\section{The Concept of Family}

Family may mean different things to different people. To accept the debate around the definition of family is to acknowledge the characteristics of an ever-changing world. Taking into consideration the diverse government policies and programmes in the United States, Sugarman (2008) submits that the concept and understanding of marriage will continue to change. For instance, whilst some may understand cohabitation 
as a sufficient basis for defining a family (Levin \& Trost, 1992), there is hardly any social welfare programme in the United States that recognises cohabitation as a qualification for family status (Sugarman, 2008); whereas many African cultures completely frown at cohabitation as a basis for defining a family. Levin \& Trost (1992) propose two possible definitions of family: "a social group consisting of at least one parent-child unit or at least one spousal unit" and "a social group consisting of at least one spousal unit and at least two parent-child units (one child with two parents who also are each other's spouses)." Some would argue that a child does not necessarily define a family in that there are instances of individuals who are legally married but have chosen not to have a child. In a related reality, some individuals would prefer to enlist their pets as part of their family. There is also a popular notion that synonymises a household with a family, and a family with a household (Levin \& Trost , 1992), which begs the question of what happens when an individual exits the household. In actual fact, the deconstruction and extension of the definition of marriage may lead to the acceptance of every segment or unit of the society as a family, if no dichotomy is drawn. In this case, a business organisation may choose to see itself as a family; an academic class may also opt to consider itself as a family regardless of the background of its members; other variations could be church family, estate family and many more. But as espoused by Corbett (2004), an endless recognition of every unit of the society as a family erodes the significance and uniqueness of the concept of family and its importance to the society. It is therefore important for every exposition that is implicated on the family to operationalise the family concept within the given context.

Consequently, for this discourse, a family is defined as networks of people who share their lives over an extended period of time and are connected by ties of marriage, blood, or commitment, legal or otherwise; and consider themselves as family with a significant history and anticipated future of functioning in a family relationship (Galvin, Bylund, \& Brommel, 2004). It is imperative to expound that the connecting ties for the family in this definition are marriage, blood, commitment and legality. The legal provision stated covers anyone who has become a member of a family by adoption, but exempts such family concept as work family, school family, church family, political family and any other form of family that is largely constructed by association. All these other associative families can be seen as family by assimilation. Nonetheless, irrespective of the shape of the family bound by ties as reflected in the operational definition of the family, it is not immune from being impacted by the fallouts of a national discourse. Likewise, the tiny conversation that occurs in the family can transmute into a subject of national discourse.

\section{The Nature of National Discourse}

"National" signifies a relationship with a nation in its entirety. The concept of a nation is one that implies much more than what it is perceived to be. Thus, it becomes challenging to define a nation within the ambit of sovereignty and territorial integrity, which are often the most pronounced characteristics of modern nations, as commonly understood. An accurate exploration of the nature of national discourse requires a considerable attention to the key inherent components of a nation and discourse. The concept of a nation is probably the most difficult to encapsulate in a universally acceptable definition. This is primarily a function of the existing propositions from diverse scholars who have carried out extensive studies in this area. Some have drawn a dichotomy between a nation and state.

Parekh (1995) submits that the three distinguishing elements of a state are its territoriality, the autonomy of the state, and the inherent monopoly of the state to apply force for its protection. Similarly, Parekh (1995) also identifies five distinctive charateristics of a nation from the viewpoint of a nationalist. The first is the cultural homogeneity of a nation, which is visible in its cultural practices, values, language and other systems of meanings. The second characteristic is the specificity of identity. A nation has a way of moulding the identity of its people in a specific way that is typical of all its members. Thirdly, a nation is always attached to a territorial preference, which is often seen as a home. Fourthly, members of a nation can lay claim to a collective descent, which they all recognise as their root, or as having a "domestic genealogies" (McClintock , 1993); and finally, there is a strong shared understanding and collective belongingness amongst members 
of a nation. As such a state with the characteristics of a nation can be addressed as a nation-state, which in reality is the status every state should strive to attain (Parekh, 1995).

Having questioned the appropriateness in using the common discernible characteristics of the modern nation in defining the concept of a nation, Renan (2000) describes a nation as a large-scale solidarity, constituted by the feeling of the sacrifices that one has made in the past and of those that one is prepared to make in the future. The sacrifices are both representative of the history of the people and the compromises that have been accepted in what they have jointly considered as a nation. Nevertheless, the definition by Anderson (2006) seems to provide a substantial level of operationality in this context. $\mathrm{He}$ defines nations as imagined political communities in limitation and sovereignty. A nation is imagined in limitation since no single nation can encompass the whole of human race; every nation is only limited to a particular set of people, which may also include different races brought together by different kinds of calculated or inadvertent transpositions (Ashaolu, 2016). In the same vein, the sovereignty of a nation as proposed by Anderson can be interpreted in the context of statehood as submitted by Parekh (1995). Finally, a nation is imagined as a community because of the comradeship of its members who will be willing to make necessary sacrifice to protect it from external agression, which can be argued in line of the proposition that war against an external aggressor can serve as a veritable tool to foster the internal unity and peace of a nation (Hegel, 1991).

Therefore, in the light of this paper, a nation can be described as a people within a geographical entity bound together by specified protocols that they (majority) can identify with. The specified protocols in this case include the sovereign government, a currency of exchange, a similar fashion leanings, lingua franca, similar colonial experience, and other protocols that may be characteristics and approved by them. At the heart of the communality of a nation are unending conversations that aid the togetherness of the people. This kind of conversation can also be referenced as discourse, also used in place of communication that occurs among and between people of a nation, but the term discourse is more fitting in this context.

Discourse is the speech-characterised communicative experience or the conversational social interaction (Van Dijk, 2006) among people. Being a conversational interaction, discourse can occur in any setting and through any means, - written, unwritten and verbal form - since literary or written communication can also be appreciated as a vocal exchange (Macovski, 1997). Discourse to a great extent is influenced by an individual's opinion, and every participant in a discourse is motivated by the intention to convey some thoughts; as such participants have inherent communicative objectives in every discursive undertaking (Ariel, 2009). This contextual opinion can also be interpreted as the individual knowledge. Therefore, knowledge is crucial to the construction and understanding of text and talk, and any account of discourse that ignores it is as good as incomplete (Van Dijk, 2006). However, the danger is that not all knowledge expressed as an opinion can be deemed accurate in a discourse. Nevertheless, the presence or absence of accuracy in an individual's opinion does not downplay the actuality of his participation in a discourse from a standpoint. Essentially, a discourse is a conversational social interaction that is predicated on a purposive subject. There is no restriction to what can become a subject of a discourse, even national discourse; and there is no delimitation to where it can take place.

On this premise a national discourse is any discourse that is noticeable in different sections and gathering within a national entity. Foucault (1981) offered a classification of societal discourse from the everyday conversation to the deep-rooted cultural nuances that are passed on from one generation to the other. In point of fact, there are many casual discourses that have simultaneously found expression and settlements in various sections of the society, which might be difficult to trace the author (Foucault, 1981). Nevertheless, when a discourse takes on the status of national pervasiveness, its origin becomes an area of interest, especially for the purpose of analysis and possible implications on units of the nation. The issues that form the national discourse of a nation normally have a strong tendency to travel miles penetrating diverse segments of the nation, including the family. It is in this regard that this paper seeks to explore the relationship between national discourse and the family in a nation. 


\section{The Media of National Discourse}

It is undeniably difficult to accurately discern the subject of discussions in every congregation of people small and large - in a nation. Still, some institutions provide a measurement that helps to aggregate the popular subject of interest in a nation. Martigny (2008) offers five actors - mass media, political elites, bureaucracy, interest groups, and intellectuals - that are responsible for the amplification of a national discourse. Extending this classification, it may be more appropriate to group the media of national discourse into two - the conventional media and the non-conventional media. Some writers (Agboola , 2014; Mhiripiri \& Chikakano, 2017) have used the term conventional media in place of traditional media, which represents those media that existed before the advent of digital media. But within this context, conventional media are seen as those recognised and regulated conduits of communication in a nation. The radio, television, print media, and any other means regulated by identified authorities can be categorised under the conventional media. On the other hand, the non-conventional media are the recognised, unregulated or pseudo-regulated but exploited means of communication in a nation. The members of this category will be social media, small group discussions, unstructured conversations at relaxation centre, and the classroom conversation in the Ivory Towers. These media of communication are responsible for the amplification of every subject of national discourse. The advent of social media which is largely uncensored and unstructured in many nations has contributed a great deal to the transportational possibility of a subject from a tiny unit of the society to national recognition. Essentially, national discourse does not progress in a vacuum; it is conveyed by a convoy of communication vehicles. Mass media, which include radio, television, and print media, appear to be the most popular and commanding of all the media of national discourse. National discourse takes place on the radio through talk shows and news. On television, the national discourse is reflected in talk shows, news, music, documentary and many more. In the newspaper, national discourse is reflected in commentary, editorial, column, and news.

The social media has considerably changed the character of national discourse. The main attributes of the social media, which are speed, timeliness, non-restrictive, multimedia, and democratisation have made it easier to make a minor issue a national discourse. The hashtag trend is so fast that it could make a trivial topic become a major issue for discussion in the shortest possible time. With a simple hashtag, many can join a conversation and widen it such that it becomes the issue that dominates the social media. When it dominates the social media, soon enough it will spill into the mainstream media and could eventually become the theme for national discourse. Now individuals spread and expand social issues from a minor conversation to a widespread discourse through social media platforms.

The convergence brought about by the digital innovation proposes that conversations in the social media sometimes become news for the conventional media; especially now that there seems to be blurred lines between what is newsworthy and otherwise. Also worthy of note is the unconventional and unstructured conversations that take place in many formal and informal settings. These media of communication have always been and will never depart this world. Formal unconventional settings are the conferences, seminars, and symposia. The informal unconventional media of national discourse are the conversations that occur in a "Beer Parlour", pub and other relaxation spots; casual natter at workplace and any other form of idea sharing that is unstructured. It must be noted that until a discourse pervades both the conventional and unconventional media it cannot be treated as a national discourse. And this pervasiveness is not necessarily predictable in time ratio. Whilst some discourses can take on a national dimension in a short while; others may take time to gain prominence into national status.

Similar to the assertion by Martigny (2008), the personalities involved in a discourse theme sometimes determine the attention given to such discourse. More often than not, the status of some individuals gives them more prominence in the society than others. In the case of politicians and people in the political space, there are more searchlights on them than other people in the environment. Therefore, when their actions are exposed, they easily become the subject of gossips and conversations. The other factor is related to the role of the media as a vehicle for national discourse. Just as the issues in a family can transcend to becoming 
topics for national discourse through the media, the media also sets the agenda for families through a national discourse. Priming by the media is a major factor that elevates or transmits family issues into national discourse and vice versa. Kuypers (2002) describes priming as the ability of the media to provide contextual cues by which subject matters are evaluated. This suggests that the media contextualise issues in a manner that sets people's mind to think of such issues in a certain way.

The repetition of messages about public issues in the news day after day, along with the pervasiveness of the mass media in our daily lives, constitutes a major source of journalism's influence on the audience (McCombs \& Valenzuela, 2007). Sometimes, the way the issues are presented in the media either angers the audience or draws the audience close. And when a news report from the media is able to elicit a certain emotion from the audience, it is inevitable for such communication to also elicit a certain kind of behaviour or action. This is further heightened by the ignorance on the part of many, which is why they rely on the media for information that will form the basis of their decisions. When families lack the knowledge needed to logically analyse a theme of national discourse they simply accept the proceeds from the media on the issue and act on it. If the media has framed the issue in a manner that purely satisfies a sectional motive, the family might be greatly affected by such communication.

The curiosity of man is a natural inherent attribute that serves as a drive for knowledge. Pisula (2009) posits that human beings are naturally inclined to be interested in knowing things that are not in the open. This concept that has also been supported by other studies, presupposes that human beings find the knowledge of what happens in people's closet interesting. Hence, when the media discuss issues of a particular family, the society generally finds it amusing with an appetite to know more about such event. In the process, it becomes a popular topic for discussion and could form the theme for national discourse.

\section{Discourse Theory}

The understanding and approach to discourse theory varies from one discipline to another depending on the rationale behind its exploration. All the same, regardless of the perspective through which the discourse is viewed, there seems to be an agreement that discourse theory aims to identify the link between the people's exchange of ideas in the society and the prevailing knowledge in the society, which eventually influences their behaviour. As Karlberg (2012) posits, discourse theory attempts to examine the "social construction and exchange of meanings through texts" in a social setting. Texts in this context refers to every form of communicative channel employed for the expression of opinions, ideas and thoughts. In his submission, Fairclough (2013) postulates that discourse theory ought to extend beyond analysing language use; rather it should focus on the processes that produce and construe texts, "and with how these cognitive processes are socially shaped and relative to social conventions, not just with texts themselves" since the components of a discourse are largely determined by the prevailing social circumstances.

The most influential figure in discourse theory is Michel Foucault whose works on discourse focused on the relationship between power and knowledge discernible by analysing discourse across time. Schneider (2013) captures Foucalt's views this way: "certain people and social groups create and formulate ideas about our world, which under certain conditions turn into unquestioned truths and start to seem normal." This appears to ascribe the control of a discourse to a particular group of people in the society. In his criticism of Foucalt's views, Panneerselvam (2000) submits that whilst modern theorists embrace the neutral, objective and universal interaction between knowledge and truth, Foucalt theorised the two as vital elements of power and domination. In essence, some actors use their knowledge to influence discourse through which they dominate the general populace. The main actor in this regard is the government which Foucalt suggests uses discouse to control the people through a process he calls "governmentality" (Foucalt, 1991).

Just like every other theory with inherent imperfections, discourse theory has been challenged for its inapplicability. Alexy (1988) posits that the theory lacks a rule system that prescribes an appropriate procedure for arriving at an exact result. Nonetheless, the theory proposes the discourse analysis method. 
Discourse theory sometimes is used synonymously with discourse analysis. Whilst the two can be treated as one, discourse analysis is essentially a methodological conceptualisation of the theory, yet the two are nearly inseparable. Discourse analysis as a term is acknowledged to have emanated from Zellig Haris (Paltridge, 2006) in his paper titled Discourse Analysis where he sought to provide a "method for the analysis of connected speech (or writing)" (Harris, 1952). "Discourse analysis looks for patterns of relationships resulting from interdependence between text content, structures, processes, and behaviours" (Cataldi, 2004). Over the years, discourse analysis has been used differently depending on the nature of research and the preference of the theorist. Whilst some theorisers favour "analysis of isolated texts" others prefer "analysis of systems of texts" (Karlberg, 2012). Other slants to discourse analysis include the structural analysis, synchronic versus diachronic analysis, and critical discourse analysis, amongst others (McKinlay \& McVittie, 2008). To briefly explicate on some of the approaches that have implicative connection to this study; whilst the synchronic analysis emphasises a definite moment in time, the diachronic analysis favours a historical perspective (Brinton, 2001).

A more pertinent approach is the critical discourse analysis, which is predicated on the theoretical assumption that popular mutual communicative patterns on a particular facet of reality implicates the social behaviours relating to that facet of reality (Karlberg, 2012). This presupposes that people are likely to behave in a way that mirrors the subject of the popular discourse in the society. In context therefore, the critical discourse analysis approach suggests that national discourse can affect behavioural patterns of individuals in the family or the family as a collective. And as Karlberg (2012) submits, the relationship between national discourse and social behaviour is dialectical, which means each influences the other (Karlberg, 2012). This premise gives credence to the assumption that events in the family also influence national discourse. In other words, a discourse within a family can grow exponentially to becoming a national discourse and in a cyclical way affect behavioural expectations and actuality within the family.

\section{The Factory and Market of National Discourse}

As established earlier, national discourse can be understood as the popular conversation within a nation state, which can influence or trigger actions from constituted authorities and the individual family unit. The power of a national discourse is such that it can change the entire course of a nation. Its influence on the family cannot be overemphasised since the family can be compelled to adjust to the realities of the issues raised in the national discourse. One may ask "where exactly does national communication emanate from?" The issues that form the basis for national discourse often come from the environment. The factory for national discourse is the nation, the people. Sometimes, the factory for national discourse may also be external - outside the geographical precincts of the country. This has become possible as a result of globalisation which has made the world a small global village (Glory, 2016).

If national discourse has a factory, then it must have a marketplace where the manufactured proceeds are distributed. In this case, the factory and marketplace of national discourse remains the nation and its people. Every segment of the nation - school, church, business, academics and family - is affected by the issues of a national discourse. Observatorily, it is plausible to suggest that the subject of a national discourse moves from the individual in a family to the unconventional space, from where it moves to the conventional media space and becomes a subject of national discourse. In the same way, a subject of national discourse can emanate from the topmost political hierarchy of a nation, such as a council meeting decision, to the conventional/unconventional media and unto the unconventional/conventional media space and ends with the individual(s) in a family.

\section{$7 \quad$ Family as a Factory of National Discourse Messages}

The family is being described as a factory for national discourse since a factory can be regarded as a production abode. Borrowing from the succint and relevant definition offered by the Singaporean Ministry of Manpower, a factory can be described as any place responsible for the making of any article or part of any article (Ministry of Manpower, 2017). As espoused by Prasad (1967), an analysis of a nation must begin 
with its basic unit, which is the family. This paper is not intended to carry out an analysis of any nation; however, the point Prasad posits speaks to the subject matter. It reflects how important the family is in the whole arrangement of a nation and the discourse that permeates the nation.

National discourse affects the family, just as the family influences the national discourse. Events and happenings in a single family can become the theme for a national discourse. Sometimes, these family events may not directly be the subject matter but they may be the human behind the masquerade that the general populace sees. The case studies discussed below will further elaborate on how the family can become the factory for national discourse. The cases purposively selected have been deliberately limited to recent events in order to truly reflect the roles of the different mediums of national discourse.

\subsection{Case One: Aisha Buhari vs Muhammadu Buhari (Nigeria)}

October 2016, Nigerian media space was inundated with headlines of how Aisha Buhari declared in an interview with the British Broadcasting Corporation, BBC, that the President (her husband) had been commandeered by some cabals within the government. She eventually declared that she would not support her husband in the next round of elections, if he declares to contest and circumstances remain the way they are. In her words "he is yet to tell me, but I have decided as his wife, that if things continue like this up to 2019, I will not go out and campaign again and ask any woman to vote like I did before. I will never do it again" (Vanguard Newspaper, 2016). Immediately, this outburst became the theme for national discourse and speculations started arising on the president's capacity to actually lead the nation. In response to the allegation by the wife, President Muhammadu Buhari in Germany few days after the BBC interview was released, said "I don't know which party my wife belongs to, but she belongs to my kitchen and my living room and the other room" (BBC, 2016). For many weeks, the revelation from the First Lady and the President's response formed the fulcrum of national discourse in Nigeria, with some international dimension. A search on Google with "my wife belongs to the kitchen and the other room" provides result of $1,050,000,000$ in 0.55 seconds which is an aggregation of online publications on the discourse from websites based in diverse countries.

The outburst remained the subject of national discourse but was characterised by different slants. Whilst some opinionators held the view that Aisha Buhari was courageous (The Guardian, 2016), others simply discarded it as inconsequential. In another instance, a group by the name Adamawa League of Women Empowerment was reported to have castigated Aisha Buhari for her action "breached the norms and values of a decent housewife of a serving president" (Punch, 2016). In a different dimension, some condemned the president for relegating the importance of womenfolk to domestic responsibilities and marital obligations. A popular Nollywood actor, Hilda Dokubo, made a 2 minutes video to negate the president's assertion. The transcript of the video reads " $\mathrm{Hi}$, my name is Hilda Dokubo and I am a woman. I do not belong to the kitchen. I go to the kitchen to fix food for my family and myself; we eat there sometimes. I don't belong there. I do not belong to the bedroom either. I sleep there, it is my rest place. My things are there but I don't belong there. I do not belong to the sitting room, it's a lounging place; I rest there and I watch television there. I do not belong to the other room, because I don't know where the other room is in my house, except this other room sounds like the toilet. I cannot belong to the toilet" (Daily Post, 2016). In the social media space, the discourse was characterised by humour, feminism, political permutations and different kinds of memes that represented the divergence in interpretation of the discourse. The event has even introduced a new slang into the Nigeria social media lexicon "the oza room" which is often used suggestively to indicate sexual interaction. Public commentators and analyst have argued that Aisha Buhari must have explored all possible domestic avenues to reach her husband with no headway. The BBC puts it this way "As the closest person to the president, she must have exhausted all avenues before criticising him in the media" (BBC, 2016). Ever since this event, the political space in Nigeria has started witnessing alignments and re-alignments in preparation for the next election. This is evident of how a family matter can become the factory for national discourse. 


\subsection{Case Two: Ese Oruru (Nigeria)}

Ese Oruru's was a young teenager in 2016 when she was forcibly married by Yunusa Dahiru (alias Yellow) who took the young girl from Yenogoa, Bayelsa State to the Emir's Palace in Kano State. The young girl was missing until the parents got information that she was with one Yunusa in Kano State. Yunusa was eventually charged to court on a 5-count charge of "criminal abduction, illicit sex, sexual exploitation and unlawful carnal knowledge of a minor" (Vanguard, 2016). Yunusa, however, pleaded not guilty before the court insisting that the girl in question willingly agreed to follow and marry him. The Emir's Palace in Kano State corroborated this claim, asserting that when Yunusa arrived the Palace, he had informed the authorities of the Palace that the lady agreed to marry him willingly. The matter was brought to the public domain by the Punch newspaper calling for public intervention. It soon became a national discourse with diverse slants.

At the court hearing diverse interests were represented in the legal battle. In fact a lawyer from the Urhobo Progressive Union was at the court representing the interest of the Urhobo people in Delta State, Nigeria where the girl's parents hail from (Vanguard, 2016). In the social media space, there was a campaign for the release of the girl using the hashtag \#FreeEse, which became a "trending" topic on Twitter and other social media space. Some saw the case as a clear case of abduction and the need for the government to strengthen laws around abduction. For some others, it was a clear case of child rights abuse and the need for the government to protect the Nigerian child. Whilst the story lasted, it was a major subject of national discourse that had religious, ethnic, cultural, social, and political dimensions to it. Again, we see how a family issue became the brewery for national discourse.

\section{Family as a Recipient of National Discourse Messages}

Having explored the nature of the family as the production house for national discourse subjects, it becomes pertinent to examine how the family becomes the marketplace for national discourse in order to further pinpoint the ambivalence in the relationship that exist between the two variables. This is to examine how the family becomes the prey of national discourse messages. The family can be affected either positively or negatively by the message in and of a national discourse. An issue that has garnered national recognition through a national discourse naturally elicits the attention and interest of the family unit, and in the process, the family becomes aware of the issue and possibly adjusts their realities to accommodate the issue.

\subsection{Case Three: 2016 Recession (Nigeria)}

The National Bureau of Statistics officially announced that Nigeria was in recession on August 31, 2016. The news became a popular topic for discussion as many Nigerians perhaps saw the news as a confirmation of the hardship they had been experiencing prior to the announcement. The popularity of this discourse was such that people started making it the locus for their incapability to respond to expected obligations. Since the last quarter of 2016 when Nigeria was officially declared to be in recession and the discussion around recession became a topic for national discourse, families started adjusting to the realities. The awareness and reaction that greeted the discourse on recession is not restricted to the economic realities alone. It became the reason for many families to adjust their lifestyles to the point of some marriages breaking up or just separating for the moment (Global News, 2017). While the recession was real and felt by many with high inflation and dwindling income, some individuals would easily react in certain when it comes to financial matters and blaming it on recession.

The former Minister of Education in Nigeria, Dr. Oby Ezekwesili triggered a hashtag on Twitter to encourage the discourse in the social media. "I wish to curate the best ideas that citizens have adopted in adjusting to the Recession. Do YOU have any? Use \#MyRecessionAdjustmentIdeas" (Ezekwesili, 2016). In response, many young Nigerians narrated the ideas they had embraced in adjusting to the recession that had become a subject of national discourse. Diana Emenyonu tweeted "I pack fruits as snack 4 my kids, hubby takes lunch $t$ wrk $n$ carpools $t$ wrk. I also carpool 4 sch runs. Sleep by $7 \mathrm{pm}$ no nid 4 gen” (Emenyonu, 2016). The conversation on Twitter also revealed how the discourse had affected roles in the family. Iworah 
tweeted "Moved to my own house to cut off rent. Stopped driving to work and goes to market myself not my wife" (Iworah, 2016). The latter part of Iworah's comment suggests the possibility of his wife spending more if she goes to the market instead; and as a result he chose to take up that role since he is probably more cautious in spending. This is indicative of how families adjusted to the prevailing discourse at the time.

As the discourse lingered, some families became more aware of the possible ways they could explore to survive the recession. When Itunu tweeted "use washing machine @ home instead of dry cleaning. Wash \& steam my hair myself instead of going [to the] Salon" (Itunu, 2016), Udezeh responded by asking "My sister, kindly share tips on the hair steaming. N5000 a week for this service is adding up quite dangerously" (Udezeh, 2016). Udezeh's tweet shows how willing she was to further adjust her life based on the prevailing discourse. Plausibly, when Udezeh adjusts her lifestyle, it will naturally extend to members of her family either by introducing the females to tips that will make them avoid salons for hair steaming or having extra cash to cater to other pressing matters. In another perspective, these adjustments will also lead to decrease in the patronage of the hair stylist who will also be compelled to adjust her family realities. The most prevalent slant to this discourse is its economic implication, which was felt by many but more popularised by the extent of the discourse. It is indicative of how a national discourse that officially emanated from a government representative as a performance of official function affected various families in the nation. Perhaps, if the discourse had not been pervasive, maybe some families would not have known about the declaration of recession and would not have had to adjust even when they were essentially not impacted by it.

\subsection{Case Four: 2016 US Election (United States of America)}

According to news report (Wood, 2017), Gayle McCormick, who was married for 22years sued for divorce after her husband voted for Donald Trump in the 2016 US Presidential Election. She lost every respect for her husband when "he casually mentioned during a lunch with friends (during election year) that he planned to vote for Trump" (Reuters, 2017) who eventually won the election. The woman suddenly realised that there were major irreconcilable differences in their marriage. The 73 year old woman states that "I was in shock, it was the breaking point. The Trump issue was the catalyst. I was tired and older and I didn't want to argue and neither of us was going to change" (USA Today, 2017). She further states "I felt like I had been fooling myself, it opened up areas between us I had not faced before. I realized how far I had gone in my life to accept things I would have never accepted when I was younger" (Reuters, 2017).

Similarly, Sue Koren claims she could barely speak to her two sons after the result of the elections. She adds: "Life is not what it was before the election." It's my anger, my frustration, my disbelief. "They think our current president is a hero and I think he's a nut" (Wood, 2017). Whilst the McCormick case was primarily marital adjustment, Koren's reaction was more of a parent-children relationship. These two cases are typical of how individuals react to national discourses, especially when others' opinion defers from theirs.

\section{Conclusion}

A discourse brings to the fore what already exists in the corners of the society. The family is largely regarded as the basic unit of a nation yet it can influence and be influenced by national discourse. This signifies the importance of every actor in the family system and participants in national discourse to realise that the nexus that exists between the family and national discourse can never be broken as long as family exists as a unit of the society. It is therefore essential for families to respect their privacy and keep family issues within the family at all times. It is also crucial for families to kill ignorance and evaluate national discourses from the perspective of an informed mind in order to prevent being swayed by media shenanigans.

Similarly, the foregoing has also shown that the media has a huge role to play in the national discourse space because it is the vehicle for national discourse. As a result, media practitioners have a responsibility in the way they conduct their business since many families are depending on their activities for information. In 
Goodluck, Adv. J Social Sci.; Vol. 1 Issue 1, pp: 01-14, November 2017

this regard, the media are responsible for exposing detrimental and dangerous happenings in the family to preserve the nation.

\section{Recommendations}

Having established the importance of media in national discourse, it is recommended that the media imbibes the true spirit of the social responsibility theory and the principles of media ethics. Similarly, individuals are encouraged to be media literate in order to make right and well-informed decisions at all times.

\section{- Social Responsibility}

Social responsibility encourages total freedom for the press with no censorship, but it should be selfregulated according to social responsibilities and expectations. Content is also filtered through public obligation and interference. The tasks of the press is to make a code of conduct and follow it, to develop a standard in journalism, to make journalism better, to protect journalists and to have penalties if any journalist violates the code of conduct. This way, the facts provided by the press are analyzed and interpreted so that the people get true information and understandable news. This helps maintain social harmony by revealing social evils like corruption and discouraging other bad conducts.

- Media Ethics

The media should embrace ethical standards in its innovation and always keep to the golden mean in all its pursuits so as to ensure that it carries out its functions without amputating other essentials of the media society. Therefore, the media must imbibe the principles of truth and accuracy, independence, fairness and impartiality, humanity and accountability to the society.

\section{- Media Literacy}

Media literacy is the ability to access, analyze, evaluate, and create media (Media Literacy Project, n.d). This requires the ability of every citizen, including families to access different media, analyse and evaluate their news report in order to form the right conclusions. This is essential because without it families will always accept news report without any form of critical analysis and that may jeopardise the decisions of family.

\section{Acknowledgment}

I would like to thank Prof. James Tar Tsaaior for his mentorship and the thought-provoking insights that led to the conception of this paper. The seed you consciously implanted has strongly germinated and grown to a pleasing sight to behold.

\section{How to Cite this Article:}

Goodluck, L. (2017, October 4). Exploring the Dialectical Relationship between National Discourse and the Family in a Contemporary World. Advanced Journal of Social Science, 1(1), 1-14. https://doi.org/10.21467/ajss.1.1.1-14

\section{References}

Agboola , A. K. (2014). The influence of new media on conventional media in Nigeria . Academic Research International , 105-113.

Alexy, R. (1988). Problems of discourse theory. Critica: Revista Hispanoamericana de Filosofia, 43-65.

Anderson, B. (2006). Imagined communities: Reflections on the origin and spread of nationalism. London and New York: Verso.

Ariel, M. (2009). Discourse, grammar, discourse. Discourse Studies, 5-36.

Ashaolu, O. O. (2016). A critical study of history and nationalist discourse in Nollywood narratives: Tunde Kelani's Saworo Ide and Agogo Èèwò. Africology: The Journal of Pan African Studies, 201-219.

Barnett, H. (1953). Innovation: The basis of cultural change. New York: McGraw-Hill.

BBC. (2016, October 14). Nigeria's President Bubari: My wife belongs in kitchen. Retrieved from BBC: http://www.bbc.com/news/world-africa-37659863 
Bolton, R. (2009). People skills. New York: Simon and Schuster.

Brinton, L. J. (2001). Historical discourse analysis. In D. Schiffrin, D. Tannen, \& H. E. Hamilt, The bandbook of discourse analysis (pp. 138-160). Malden and Oxford: Blackwell.

Buzan, T. (1984). Make the most of your mind. New York: Simon \& Schuster.

Cataldi, B. J. (2004). Foucalt's discourse theory and methodology: An application to art education policy discourse 19702000. Retrieved September 7, 2017, from Electronic Theses and Dissertations Center: https:// etd.ohiolink.edu/!etd.send_file?accession $=$ osu1089160056\&disposition=inline

Conrad, K. (2004). Locked in the family cell: Gender, sexuality, and political agency in Irish national discourse. Madison and London: The University of Wisconsin Press.

Corbett, A. (2004). What is a family? And why it matters. Tasmania: Tasmania Family Institute.

Daily Post. (2016, October 17). I do not belong to the kitchen, other room - Hilda Dokubo condemns Bubari's comment. Retrieved from Daily Post: http://dailypost.ng/2016/10/17/not-belong-kitchen-room-hildadokubo-condemns-buharis-comment/

Dan, L. (2007). key themes in media theory. Berkshire: Open University Press.

Dutta, S. (2013). Business communication. Delhi: PHI Learning Ltd.

Eastmond, M. (1998). Nationalist discourses and the construction of difference: Bosnian Muslim refugees in Sweden. Journal of Refiigce Studies, 161-181.

Emenyonu, D. (2016, November 21). i pack fruits as snack 4 my kids, hubby takes lunch t wrk n carpools t wrk. I also carpool 4 sch runs. Sleep by $7 \mathrm{pm}$ no nid 4 gen. Retrieved September 12, 2017, from https://twitter.com/dianeemenyonu/status/800721191736582144

Enrique, J. A., Howk,, H. R., \& Huitt, W. G. (2007). An overview of family development. Educational Psychology Interactive. Retrieved September 12, 2017, from http://www.edpsycinteractive.org/papers/family.pdf

Ezekwesili , O. (. (2016, November 21). "I wish to curate the best ideas that citizens have adopted in adjusting to the Recession. Do YOU have any? Use,\#MyRecessionAdjustmentIdeas.". Retrieved September 12, 2017, from Twitter: https://twitter.com/obyezeks/status/800688460101255168

Fairclough, N. (2013). Language and power (2nd ed.). London and New York: Routledge.

Foucalt, M. (1991). Governmentality. In G. Burchell, C. Gordon, \& P. Miller, The Foucalt effect: Studies in governmentality (pp. 87-104). Chicago: The University of Chicago Press.

Foucault, M. (1981). The order of discourse. In R. Young, Unifying the text: A post-structuralist reader (pp. 4878). Boston, London and Henley: Routledge \& Kegan Paul Ltd.

Francis, D., \& Bessant, J. (2005, March). Targeting innovation and implications for capability development. Technovation, 25(3), 171-183.

Galvin, K. M., Bylund, C. L., \& Brommel, B. J. (2004). Family Communication: Cohesion and Change. London: Pearson A and B.

Global News. (2017, April 4). Marriages suffer crisis as recession bites harder. Retrieved September 12, 2017, from Global News: http://www.globalnewsnig.com/marriages-suffer-crisis-recession-bites-harder/

Godin , B. (2008). Innovation: The history of a category. Retrieved from Science, Technology and Innovation : Intellectual and conceptual histories: http://www.csiic.ca/PDF/IntellectualNo1.pdf

Hannawa, A. (2017). Interpersonal communication: Challenges, processes, and issues. In A. Hannawa, A. Wu, \& R. Juhasz, New horizons in patient safety: Understanding communication: Case Studies (pp. 31-44). Berlin/Boston: Walter de Gruyter.

Harris, Z. S. (1952). Discourse analysis. Language, 1-30.

Hegel, G. W. (1991). The philosophy of right. In A. W. Wood, Hegel: Elements of the Philosophy of Right (H. Nisbet, Trans.). Cambridge: Cambridge University Press.

Itunu (2016, November 21). use washn machine @ home instead of dry cleaning.Wash \& steam my hair myself instead of going 2d Salon. Retrieved from https://twitter.com/itunu3/status/800969378745487360 
Goodluck, Adv. J Social Sci.; Vol. 1 Issue 1, pp: 01-14, November 2017

Iworah, E. (2016, November 21). Moved to my own house to cut off rent. Stopped driving to work and goes to mrket my self not my wife. Retrieved September 12, 2017, from https://twitter.com/EmmaIworah/status/800709482456162305

Johnson, D. W. (1978). The importance of interpersonal skills. In S. L. Tubbs, \& R. M. Carter, Shared experiences in buman communication (pp. 21-25). Rochelle Park: Transaction Publishers.

Karlberg, M. (2012). Discourse theory and peace. In D. J. Christie, The Encyclopedia of Peace Psychology (pp. 347-351). Chichester: Wiley-Blackwell.

Kuypers, J. (2002). Press bias and politics: How the media frame controversial issues. Wesport: Praeger Publishers.

Lasswell, H. (1948). The structure and function of communication in society. New York: Harper \& Bros.

Levin , I., \& Trost , J. (1992). Understanding the concept of family . Family Relations, 348-351.

Macovski, M. (1997). Introduction/textual voices, vocative texts: Dialogue, linguistics and critical discourse. In M. Macovski, Dialogue and critical discourse: Language, culture, critical theory (pp. 3-28). New York and Oxford: Oxford University Press.

Martigny, V. (2008). Who speaks for France? Defining a 'national discourse' in a political science research. Second Graduate Network Conference: "Understanding Complexity: Methodology and Research Design in the Social Sciences", Central European University, (pp. 1-11). Retrieved September 4, 2017, from https://www.academia.edu/5835115/Who_speaks_for_France_Defining_a_national_discourse_ in_a_political_science_research

McClintock, A. (1993). Family feuds: Gender, nationalism and the family. Feminist Review, 61-80.

McCombs, M., \& Valenzuela, S. (2007). The agenda setting theory. Retrieved from Scientific Information System Redalyc : http://www.redalyc.org/comocitar.oa?id=97120369004

McKinlay, A., \& McVittie, C. (2008). Social psychology and discourse. Chichester: Wiley-Blackwell.

Media Literacy Project. (n.d.). What is Media Literacy? Retrieved from Media Literacy Project: http://medialiteracyproject.org/learn/media-literacy/

Mhiripiri, N. A., \& Chikakano, J. (2017). Criminal defamation, the criminalisation of expression, media and information dissemination in the digital age: A legal and ethical perspective. In N. A. Mhiripiri, \& T. Chari, Media law, ethics, and policy in the digital age (pp. 1-24). Hershey: IGI Global.

Ministry of Manpower. (2017, March 21). WSH Act: what is a factory. Retrieved from Ministry of Manpower: http://www.mom.gov.sg/workplace-safety-and-health/factory-notification-andregistration/what-is-a-factory

Mizzoni, J. (2010). Ethics: The basics. Chichester: Wiley-Blackwell.

Nadeau, R. E. (1969). A basic rhetoric of speech-communication. Boston: Addison-Wesley.

Paltridge, B. (2006). Discourse analysis: An introduction. London and New York: Continuum.

Panneerselvam, S. (2000). A critique of Foucalt's knowledge and power. Indian Philosophical Quarterly, 13-28.

Parekh, B. (1995). Ethnocentricity of the nationalist discourse. Nations and Nationalism, 25-52.

Pejovich, S. (1996). Property rights and technological innovation. In E. F. Paul, F. D. Miller, Jr., \& J. Paul, Scientific innovation, philosophy, and public policy (pp. 168-180). Cambridge: Cambridge University Press.

Pisula, W. (2009). Curiosity and information seeking in animal and buman behavior. Boca Raton: BrownWalker Press.

Prasad, A. (1967). The basis of society. Bombay: Sirur Printing Press.

Punch. (2016, October 27). Aisha's outburst breached norms, values of a decent wife -Women's group. Retrieved from Punch: http://punchng.com/aishas-outburst-breached-norms-values-decent-wife-womensgroup/

Renan , E. (2000). What is nation? In H. K. Bhabha, Nation and narration (pp. 8-22). London and New York: Routledge.

Reuters. (2017, February 7). From disputes to a breakup: wounds still raw after U.S. election. Retrieved September 12, 2017, from Reuters: http://www.reuters.com/article/us-usa-trump-relationshipsinsight/from-disputes-to-a-breakup-wounds-still-raw-after-u-s-election-idUSKBN15M13L

Robertson, T. S. (1967). Process of innovation and the diffusion of innovation. Journal of Marketing, 14-19. 
Exploring the Dialectical Relationship between National Discourse and the Family in a Contemporary World

Schneider, F. (2013, May 6). Getting the hang of discourse theory. Retrieved from Politics East Asia: http://www.politicseastasia.com/studying/getting-the-hang-of-discourse-theory/

Sugarman, S. D. (2008). What is a "family"? Conflicting messages from our public programs. Family Law Quarterly, 231-261.

The Guardian. (2016, October 26). Aisha Bubari's courage. Retrieved from The Guardian: https://guardian.ng/opinion/aisha-buharis-courage/

Tirumalesh, K. V. (1999). Grammar and communication: Essays on the form and function of language. New Delhi \& Mumbai: Allied Publishers Limited.

Udezeh, C. @. (2016, November 21). My sister, kindly share tips on diy hair steaming. N5000 a week for this service is adding up quite dangerously. Retrieved September 12, 2017, from https://twitter.com/chidi_appanage/status/801002875518324736

USA Today. (2017, February 9). Woman ends 22-year marriage over husband's support for Trump. Retrieved September 12, 2017, from USA Today: https://www.usatoday.com/story/news/nation/2017/02/09/woman-ends-22-year-marriageover-husbands-support-trump/97686178/

Usher, A. P. (1954). A bistory of mechanical invention. Cambridge: Harvard University Press.

Van Dijk, T. A. (2006). Discourse, context and cognition. Discourse Studies, 159-177.

Vanguard. (2016, June 9). Ese Oruru : State vs Yunusa, the case so far. Retrieved from Vanguard: https://www.vanguardngr.com/2016/06/ese-oruru-state-vs-yunusa-case-far/

Vanguard Newspaper. (2016, October 14). Buhari's government has been hijacked by cabal - Aisha Bubari. Retrieved from Vanguard: http://www.vanguardngr.com/2016/10/buharis-government-hasbeen-hijacked-by-cabal-aisha-buhari/

Williams, R. (1983). Keywords: A vocabulary of culture and society. New York : Oxford University Press.

Wood, V. (2017, February 7). Dumped for Trump: Wife files for divorce after husband votes for Republican firebrand. Retrieved from Express: http://www.express.co.uk/news/world/764450/Donald-Trumpdivorce-argument-family-Gayle-McCormick-US-election-Hilary-Clinton-poll

Ziemnowicz, C. (2013). Joseph A. Schumpeter and innovation. In E. G. Carayannis, Encyclopedia of creativity, invention, innovation and entrepreneurship (pp. 1171-1176). New York: Springer New York.

\section{Publish your research article in AIJR journals-}

$\checkmark$ Online Submission and Tracking

$\checkmark$ Peer Reviewed

$\checkmark$ Rapid decision

$\checkmark$ Immediate Publication after acceptance

$\checkmark$ Open Access (Articles freely available online)

$\checkmark$ Retain full copyright of your article.

Submit your article at journals.aijr.in 